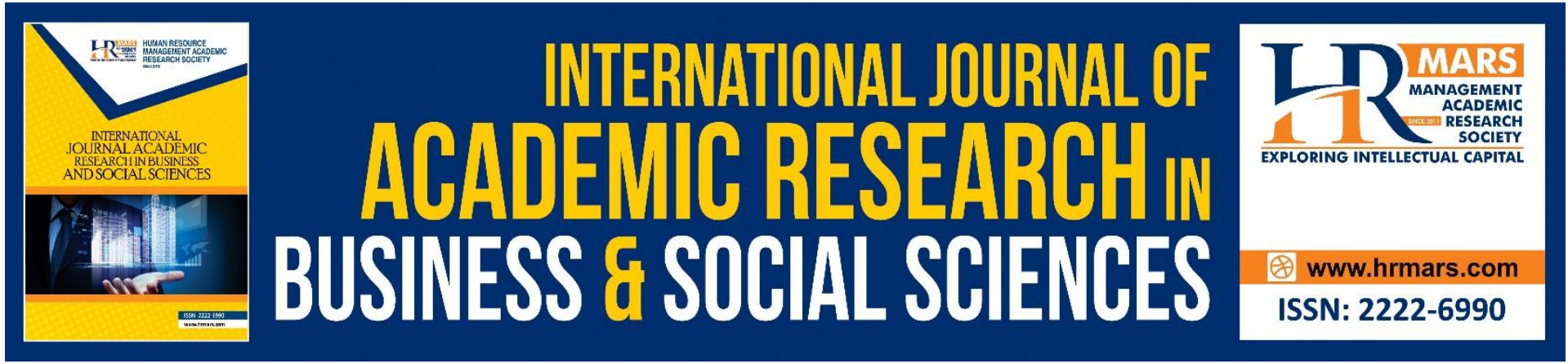

\title{
Government Support, Stakeholder Engagement and Social Entrepreneurship Performance: An Exploratory Factor Analysis
}

Putri Aliah Mohd Hidzir, Shafinar Ismail, Erne Suzila Kassim

To Link this Article: http://dx.doi.org/10.6007/IJARBSS/v11-i7/10441

DOI:10.6007/IJARBSS/v11-i7/10441

Received: 18 May 2021, Revised: 20 June 2021, Accepted: 10 July 2021

Published Online: 25 July 2021

In-Text Citation: (Hidzir et al., 2021)

To Cite this Article: Hidzir, P. A. M., Ismail, S., \& Kassim, E. S. (2021). Government Support, Stakeholder Engagement and Social Entrepreneurship Performance: An Exploratory Factor Analysis. International Journal of Academic Research in Business and Social Sciences, 11(7), 1604-1618.

Copyright: (c) 2021 The Author(s)

Published by Human Resource Management Academic Research Society (www.hrmars.com)

This article is published under the Creative Commons Attribution (CC BY 4.0) license. Anyone may reproduce, distribute, translate and create derivative works of this article (for both commercial and non-commercial purposes), subject to full attribution to the original publication and authors. The full terms of this license may be seen at: http://creativecommons.org/licences/by/4.0/legalcode

Vol. 11, No. 7, 2021, Pg. 1604 - 1618

Full Terms \& Conditions of access and use can be found at http://hrmars.com/index.php/pages/detail/publication-ethics 


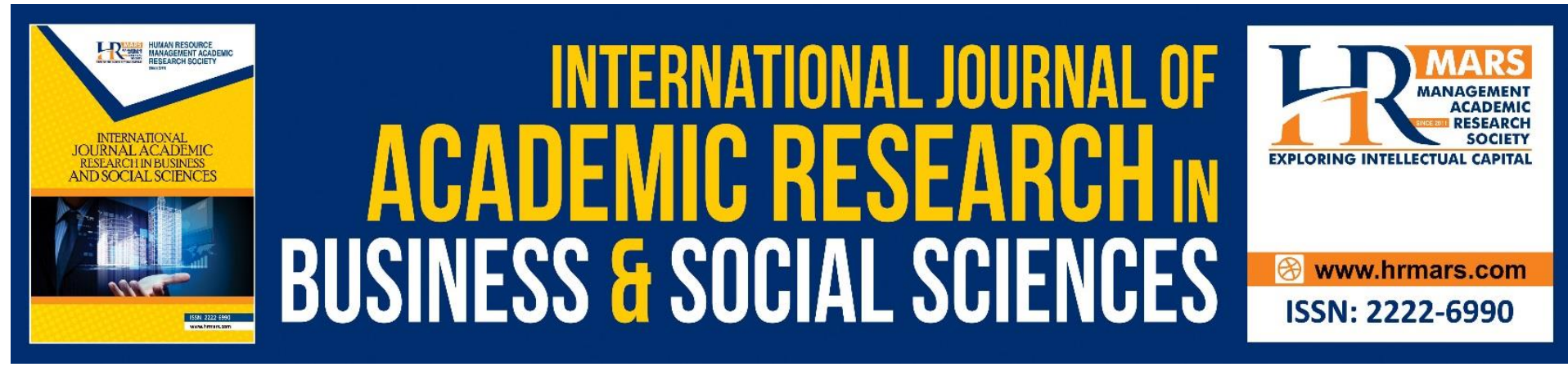

\title{
Government Support, Stakeholder Engagement and Social Entrepreneurship Performance: An Exploratory Factor Analysis
}

\author{
Putri Aliah Mohd Hidzir ${ }^{1}$, Shafinar Ismail², Erne Suzila Kassim ${ }^{3}$ \\ ${ }^{1}$ Faculty of Business and Management, Universiti Teknologi MARA, Shah Alam, Selangor, \\ Malaysia, ${ }^{2}$ Faculty of Business and Management, Universiti Teknologi MARA, Cawangan \\ Melaka, Kampus Bandaraya Melaka, Malaysia, ${ }^{3}$ Faculty of Business and Management, \\ Universiti Teknologi MARA Cawangan Selangor, Kampus Puncak Alam, Malaysia
}

Email: aliahidzir@gmail.com

\begin{abstract}
Social entrepreneurship is one of the initiatives to eliminate and minimise social issues. While there are many factors that determine social entrepreneurship performance, the importance of government support and stakeholder engagement in modelling the performance is yet to be fully explored. In line with the government's effort in certifying the status of social entrepreneurship through Social Enterprise Accreditation (SEA) in Malaysia, it is important to figure out what characterizes organization performance to thrive in the sector. Therefore, the research objective is to explore and validate the measurement instrument for social entrepreneurship performance model. A self-administered questionnaire was distributed towards social enterprises in Malaysia with the help of Malaysian Global Innovation and Creativity Centre (MaGIC) by using purposive sampling technique.. Exploratory Factor Analysis (EFA) was then carried out by using Statistical Package for the Social Sciences (SPSS) version 20. Based on the results, there are five constructs that are interrelated and form the model which are government support, community/ local resident engagement, employee engagement, organization contribution and social entrepreneurship performance. Notably, major finding of this study is the measurement instrument proved to have four underlying factors measuring social entrepreneurship performance (community/local resident stakeholder, government support, employee stakeholder engagement, organization contribution), instead of just two (government support, stakeholder engagement). The authors suggest future research to employ the developed measurement instrument in a larger sample size to better understand the performance of social entrepreneurship in a different context of study. The analyses presented in this research can be used by policymakers towards the growth and performance of social entrepreneurship in Malaysia. The findings achieved in this research will be of interest for practitioners and academics concerned with developments of social entrepreneurship in Malaysia.
\end{abstract}

Keywords: Social Entrepreneurship Performance, Government Support, Stakeholder Engagement, Exploratory Factor Analysis, Malaysia 


\section{Introduction}

Social entrepreneurship is an evolving generation of entrepreneurs that encourages businesses to support the community it resides in (Teck, Karuppiah, \& Hoo, 2020). Numerous researchers have different perspectives on social entrepreneurship. In a study, it is stated that social entrepreneurship is a business activity with social purpose (Austin, Stevenson, \& WeiSkillern, 2012) while another study states that social entepreneurship develops its presence in a country to overcome social issues (Adnan, Yusoff, \& Ghazali, 2018). In another point of view, social entrepreneurship focuses on creating a profitable enterprise by efficiently securing and handling capital and developing their business capability (Meyskens, Robb-Post, Stamp, Carsrud, \& Reynolds, 2010). The success of a social enterprise reflects their ability to survive (Moizer \& Tracey, 2010) which means the better they perform, the higher the chance they get for their business to flourish.

Social entreprise is becoming essential in sustaining the goals for improving the social purposes. Unlike traditional business, social enterpises need government support and stakeholder engagement to enable them to perform and achieve the aims more effectively. As many initiaves emerge to support social enterprises, the public and research interests towards the subject also intensify. It is therefore important to reconstruct instrument and scales in relating government support and stakeholder engagement towards social entrepreneurship performance that would be valuable to researchers, government agencies and social enterprises.

The outline of this paper begins with the review of literature on social entrepreneurship, government support and stakeholder engagement. Then it describes the item measurement and steps involves in the scale development. The final section discusses applications of the scale.

\section{Literature Review}

Initially, social entrepreneurship emerged from the social economy which emphasizes on nonprofit approaches that seek to maximize social wealth, while allowing for social and community growth (Caroline \& Antonio, 2011). Rising societal engagement makes people acknowledge how social entrepreneurship may act as an alternative tool in empowering economy for disadvantaged groups (Kassim et al., 2020).

\section{Social Entrepreneurship Performance}

Social enterprise performance is an important aspect to be assessed because it could be helpful for the firm to make necessary decision to improve their efficiency (Arena \& Azzone, 2005). Social enterprises consist of special criteria which assist in serving social and economic objectives. Nevertheless, it is demanding for social enterprises to establish value for the society while pursuing the economic objective when they are having resources and support constraints as compared to commercial enterprises (Shin, 2018). Social performance is understood as an element of social enterprise sustainable development (Moizer \& Tracey, 2010) while other cases may identify financial achievement as the element of sustainable social enterprise (Defourny \& Nyssens, 2010; Jenner, 2016). A social enterprise is said to attain their desired outcomes if they benefit the constituency they are seeking to serve successfully, grow according to plan, and gain funding or generate revenue stream (Arogyaswamy, 2017). Moreover, in a research by Drechsler and Natter (2012), it is suggested that the importance of social enterprise includes serving the society and giving economic value to the community. In addition, Galera and Borgaza (2009) interpreted social enterprise performance as the firm's 
financial stability which is commercially viable and used "sustainable" term, whereas some have described sustainability as being able to serve both social and commercial performances, or either one, by using different methods to assess it (Shin, 2018). In line with a previous study by Shin (2018), this paper defines social enterprise performance as the value creation towards community by developing both social and financial performances. It can be measured through the social performance and economic performance of social enterprises.

Assessing the performance of social enterprises is essential towards solving the problems faced by SEs. This is be supported Syrja, Sjogren, and IImarinen (2015) who highlighted that to enhance decision making and establish transparency for their clients, social firms must begin to evaluate their success in a structural manner. Since the efficiency of social enterprise has only recently been analysed, the studies and literature are still minimal (Crucke \& Decramer, 2016). Thus, in this present study, the researchers intend to study the performance of social enterprise in Malaysia as an effort towards evaluating the success of the sector.

\section{Government Support}

In Malaysia, managing a social firm is quite tough compared to other countries that have successfully deployed a master plan or policy in promoting the growth of social firms such as South Korea and the United States (Zainol, Zainol, Ibrahim, \& Afthanorhan, 2018). The lack of legal framework in Malaysia has made it difficult for social enterprises due to the question arises on their legal status as an enterprise. A study by British Council (2018) pointed out that approximately 43 per cent of social enterprises in Malaysia are registered as private companies, 19 per cent registered as sole proprietorships, 11 per cent as societies, and 7 per cent has not registered their businesses at all. Since legislation in Malaysia is not compatible with the definition of social enterprise itself (MaGIC, 2015), this may force them to make do with the current structure.

In relation to this, it was also found that legal policy and framework for social enterprises appear to aid in providing conducive environment for their development in serving the community (Galera \& Borzaga, 2009). The ability to register as a legal entity provides firms with various benefits such as tax exemption (British Council, 2018) and thus, enables them to engage in greater communities. According to Zahra, Newy, and Li (2014), it is suggested the involvement of government can assist in increasing social enterprises' influence towards the society. Besides, gaining legitimacy is possible with the help of government support (Meyskens, Robb-Post, Stamp, Carsrud, \& Reynolds, 2010) which can contribute to firm's sustainability (Zahra et al., 2014).

Government support can be considered as an important element towards SE performance. It can be measured by the ability of social enterprises to attract government assistance (Bacq \& Eddleston, 2018). Di Domenico, Haugh, and Tracey (2010) concluded in their study that support received from government may overcome the constraints faced by social enterprises by helping them procure scarce assets and resources. On the other hand, lack of government aid will restrict the capability of social organizations to serve beneficiaries and inform members of society of social issues in the area (Santos, 2012). An essential element that separates social enterprises with a significant social impact may be the ability to attract government funding (Bacq \& Eddleston, 2018).

\section{Stakeholder Engagement}

Stakeholder participation is measured by the capacity of social entrepreneurship to connect and collaborate actively with donors, sponsors, clients, and communities (Lumpkin, Bacq, \& 
Pidduck, 2018). Participation of stakeholders in evaluation of the company enables firms to seek opportunities associated with their purpose (Smith \& Woods, 2014). Organisations need to engage with the environment to acquire various resources necessary for their survival because they are not self-sufficient (Pfeffer \& Salancik, 1978). Thus, in order to improve the barriers faced towards significant social impacts, it is important for social enterprises to seek social change by engaging various stakeholders (Pearce \& Doh, 2005).

Stakeholder engagement is important towards SE performance because it strengthens the relationship among the parties involved. In addition to developing new connections and acquiring valuable resources, stakeholder participation is essential in improving business investment (Di Domenico, Haugh, \& Tracey, 2010). Geographical expansion would be limited without engaging stakeholders regarding firm's objectives and social mission (Renko, 2013). This is supported by Zahra et al (2009) which stated that a number of social enterprises that are unable to achieve significant social impact were due to the failure in educating stakeholders adequately about the flaws in the community. Montgomery et al. (2012) found that social enterprises also seem to face problems in gathering resources and gain business credibility. Consequently, failure to interact with shareholders will result in higher challenges faced and thus, compromises their performance.

Gaining support and initiating changes for social enterprise's objective can be an easy task if firms are able to take advantage of their social network (Alvord, Brown, \& Letts, 2004). Informing stakeholders regarding firm's social mission and objective may help in building trust between the community and beneficiaries (Zahra, Newey, \& Li, 2014). In return, support from stakeholders will increase (Di Domenico et al., 2010). According to Bloom and Chatterji (2009), achievement of a social enterprise in persuading potential stakeholders through communication and interaction to support the importance of its social purpose has a high chance to signify the scale of social effects. Therefore, based on past arguments, stakeholder engagement could contribute to performance of social entrepreneurship.

Among the various models describing and measuring performance of organisations, the Resource Based View theory has commonly been referred to (Ahmed, Khuwaja, \& Othman, 2018). According to Barney (1991), the theory deems that enterprises require different types of organizational resources such as capability resources, technological resources, administrative experience, and information resources. Therefore, based on the discussion above, the following theoretical framework is developed. The framework comprises of social entrepreneurship performance, government support, and stakeholder engagement.

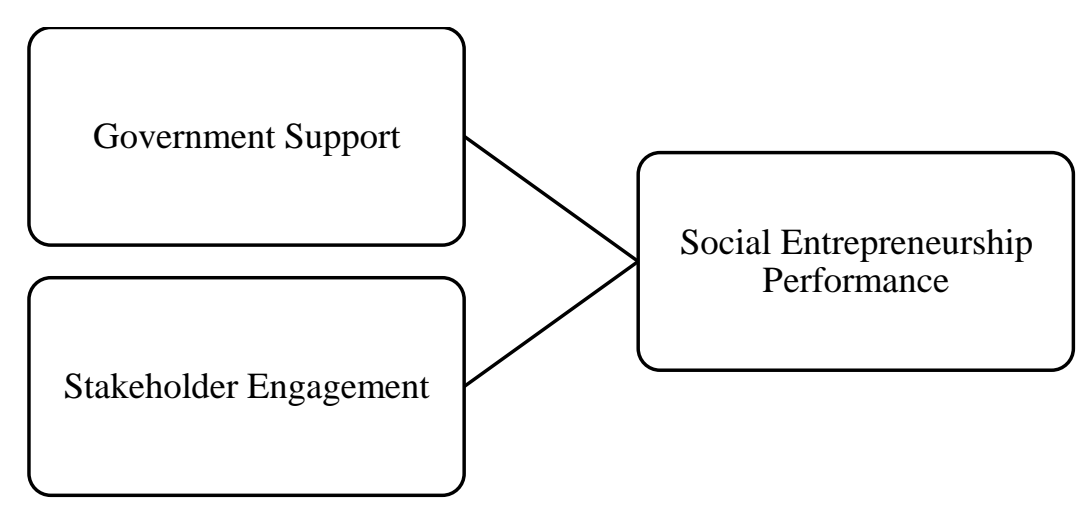

Figure 1: Theoretical Framework 


\section{Methodology}

\section{Research Instrument}

The research instrument used in the present study is a self-administered questionnaire which comprised 33 items. Each of the items was measured using a 5-point Likert scale measuring organisation performance. Those 33 questions consisted of seven items on demographical information, seven items measuring government support, 13 items measuring stakeholder engagement, and six items measuring social entrepreneurship performance. The measurement was based on the organisation's last three years of operation to ensure that only the most recent information was obtained.

\section{Sample of Study and Data Collection}

The questionnaires were distributed to social organisations listed by Malaysian Global Innovation and Creativity Centre (MaGIC) in Malaysia. This is because they fall under the definition of "social entrepreneurship" set out by MaGIC itself, an organisation that facilitates the development of the sector. This study used the term social enterprise as a company incorporated in Malaysia under any law that makes a significant social or environmental effect while being financially viable. The questionnaires were distributed through e-mail due to convenience, especially during the restricted interstate travel and the Movement Control Order (MCO) due to the COVID-19 pandemic. In total, 30 data set was drawn from the sample. Although the number is small, according to de Winter et al., (2009), when data are well conditioned, running an exploratory factor analysis as part of instrument development procedure can yield reliable results for $\mathrm{N}$ below 50 .

\section{Data Analysis}

Data analysis was conducted to ascertain the accuracy of the items used in this study. Thus, the Exploratory Factor Analysis (EFA) was carried out in Statistical Package for the Social Sciences (SPSS) version 20 to examine the factor structure of the scale. In other words, EFA was carried out to find groups of variables that are highly intercorrelated (Berg, 2021). The factor extraction method used was the principal component analysis and the rotation method was the Variation Maximization rotation (Varimax). A Kaiser-Meyer-Olkin test and Bartlett's Test of Sphericity were also carried out to ensure the data set was applicable for factor analysis (Richard \& Dean, 2007). The factorability exists if the Bartlett's test is significant, and the KMO value is greater than 0.50 (Kaiser, 1974).

A reliability analysis was next conducted to measure variables involved through Cronbach's Alpha value which can show the strength of items in each variable and their relationship with one another. According to Zulkepli, Sipan and Jibril (2017), previous researchers argued that the widely accepted alpha value should be 0.70 or higher for a set of items to be acceptable. However, there are also some that use 0.75 or 0.80 , while the others allow value as low as 0.60 .

\section{Result and Discussion Demographic Analysis}

All the 30 organisations participated in the study were registered under any written law in Malaysia and sold goods and services in the market to create return on investment for their organisations. $50 \%$ of the organisations were registered as public limited companies (Berhad), $26.67 \%$ as sole proprietorships, $13.33 \%$ as partnerships, $3.33 \%$ as societies, and $6.67 \%$ as cooperatives. Out of the 30 organisations, 18 of them had been operating for 1-5 years, 11 of 
them for $6-10$ years, and only one of them for $16-20$ years. $76.67 \%$ of the organisations were in the central region, $10 \%$ were in the east coast region, $10 \%$ were in the southern region, and another $3.33 \%$ were in the northern region of Malaysia.

\section{Descriptive Analysis}

Table 1 shows a total of 26 items in the instrument. Government support was measured with seven items, stakeholder engagement has 13 items, and social entrepreneurship performance has 6 items. The descriptive analysis was run to summarize the characteristic of the data obtained.

Table 1: Descriptive Analysis for Social Entrepreneurship Performance

\begin{tabular}{|c|c|c|c|}
\hline Code & Items & Mean & $\begin{array}{l}\text { Standard } \\
\text { Deviation }\end{array}$ \\
\hline GS1 & $\begin{array}{l}\text { We have been active in having government departments to } \\
\text { support our activities financially }\end{array}$ & 3.17 & 1.315 \\
\hline GS2 & $\begin{array}{l}\text { The governments have provided us with advantageous } \\
\text { policies }\end{array}$ & 3.00 & 1.083 \\
\hline GS3 & $\begin{array}{l}\text { We are able in bringing our purpose to a greater position on } \\
\text { the public agenda }\end{array}$ & 3.57 & 1.006 \\
\hline GS4 & $\begin{array}{l}\text { The government has supported us with necessary } \\
\text { technology information }\end{array}$ & 2.93 & 1.112 \\
\hline GS5 & $\begin{array}{l}\text { The government has supported us in seeking financial } \\
\text { resources }\end{array}$ & 3.23 & 1.104 \\
\hline GS6 & We have received beneficial projects from the government & 2.67 & 1.061 \\
\hline GS7 & $\begin{array}{l}\text { We have received direct financial assistance from the } \\
\text { government }\end{array}$ & 2.77 & 1.073 \\
\hline SE1A & $\begin{array}{l}\text { Employee stakeholders have the influence and power over } \\
\text { our corporate decisions }\end{array}$ & 3.57 & 0.971 \\
\hline SE2A & $\begin{array}{l}\text { Employee stakeholders are viewed by the management } \\
\text { team as being proper and/or appropriate }\end{array}$ & 3.83 & 0.791 \\
\hline SE3A & $\begin{array}{l}\text { Employee stakeholders usually receive high priority from } \\
\text { our management team }\end{array}$ & 3.97 & 1.098 \\
\hline SE4A & $\begin{array}{l}\text { Employee stakeholders usually receive a high degree of time } \\
\text { and attention from our management team }\end{array}$ & 3.97 & 0.809 \\
\hline SE5A & $\begin{array}{l}\text { Satisfying employee stakeholders' claims has been } \\
\text { important to our management }\end{array}$ & 4.07 & 0.907 \\
\hline SE1B & $\begin{array}{l}\text { Community stakeholders have exhibited urgencies in their } \\
\text { relationship with our firm }\end{array}$ & 3.83 & 0.747 \\
\hline SE2B & $\begin{array}{l}\text { Community stakeholders have been active in pursuing } \\
\text { claims-demands or desires which they deem important }\end{array}$ & 3.63 & 0.809 \\
\hline SE3B & $\begin{array}{l}\text { Community stakeholders usually urgently communicate } \\
\text { their claims to our firm }\end{array}$ & 3.57 & 0.898 \\
\hline SE4B & $\begin{array}{l}\text { Community stakeholders are usually viewed by our } \\
\text { management team as being legitimate }\end{array}$ & 3.50 & 0.820 \\
\hline SE1C & $\begin{array}{l}\text { Local resident stakeholders have the power to enforce their } \\
\text { claims to our firm }\end{array}$ & 3.40 & 0.968 \\
\hline
\end{tabular}


INTERNATIONAL JOURNAL OF ACADEMIC RESEARCH IN BUSINESS AND SOCIAL SCIENCES Vol. 11, No. 7, 2021, E-ISSN: 2222-6990 @ 2021 HRMARS

\begin{tabular}{|l|l|l|l|}
\hline Code & Items & Mean & $\begin{array}{l}\text { Standard } \\
\text { Deviation }\end{array}$ \\
\hline SE2C & $\begin{array}{l}\text { Local resident stakeholders have exhibited urgencies in } \\
\text { their relationship with our firm }\end{array}$ & 3.43 & 0.935 \\
\hline SE3C & $\begin{array}{l}\text { Local resident stakeholders have been active in pursuing } \\
\text { claims demands or desires which they deem important }\end{array}$ & 3.50 & 0.938 \\
\hline SE4C & $\begin{array}{l}\text { Local resident stakeholders usually urgently communicate } \\
\text { their claims to our firm }\end{array}$ & 3.47 & 0.937 \\
\hline SEP1 & $\begin{array}{l}\text { We are creating employment for the socially disadvantaged } \\
\text { class. }\end{array}$ & 4.07 & 0.907 \\
\hline SEP2 & $\begin{array}{l}\text { We help inform the community on our beneficiaries' } \\
\text { situation }\end{array}$ & 3.87 & 1.042 \\
\hline SEP3 & We operate in a socially sustainable manner & 4.10 & 0.923 \\
\hline SEP4 & Our business is eco-friendly & 4.13 & 1.137 \\
\hline SEP5 & Our business is social friendly & 4.50 & 0.682 \\
\hline SEP6 & $\begin{array}{l}\text { We set aside over two-thirds of surplus revenue for dividend } \\
\text { for social purpose }\end{array}$ & 3.33 & 1.093 \\
\hline & Mean & 3.57 & \\
\hline
\end{tabular}

Mean is used to determine the score's central tendency. The standard deviation, on the other hand, measures how dispersed the data values are around the mean. It is a measurement of how concentrated the data is around the mean; the lower the standard deviation, the more concentrated the data are. The mean score for the six items in the government support construct ranged from 2.67 for item GS6, to highest mean of 3.57 for item GS3. The standard deviation ranged from 1.006 for item GS3, to 1.315 for item GS1.

Next, for stakeholder engagement, the mean score for its 13 items ranged from 3.40 for item SE1C, to 4.07 for item SE5A. The standard deviation ranged from 0.747 for item SE1B, to 1.098 for item SE3A. Meanwhile, the mean score for social Entrepreneurship performance ranged from 3.33 for item SEP6, to 4.50 for item SEP5. The standard deviation ranged from 0.682 for item SEP5, to 1.137 for item SEP4.

Overall, the lowest mean score among all 26 items is 2.67 for item GS6 (We have received beneficial projects from the government) and the highest mean score is 4.50 for item SEP5 (Our business is social friendly). In general, all the constructs have a mean value of 3.57. According to the results obtained above, all constructs helped to explain the general performance of social entrepreneurship in Malaysia. Variation in the type of business entity, operating years, and location may cause a high standard deviation for items.

\section{Reliability Analysis}

The reliability measurement was carefully tested to ensure the quality of questionnaire. In this study, it was found that the variable of Government Support has a Cronbach's Alpha value of 0.886 while Stakeholder Engagement has a Cronbach's Alpha value of 0.942, and Social Entrepreneurship Performance's value is 0.837 . In this case, all the variables are deemed appropriate. The result is shown in Table 2. 
Table 2: Result of Reliability Analysis

\begin{tabular}{llll}
\hline Variable & Cronbach's Alpha & $\begin{array}{l}\text { Cronbach's } \\
\text { Based } \\
\text { Standardized Items }\end{array}$ & $\begin{array}{c}\text { Alpha } \\
\text { on }\end{array}$ \\
\hline $\begin{array}{l}\text { Government Support } \\
\text { Stakeholder }\end{array}$ & 0.886 & 0.883 & 7 \\
$\begin{array}{l}\text { Engagement } \\
\text { Social }\end{array}$ & 0.942 & 0.943 & 13 \\
$\begin{array}{l}\text { Entrepreneurship } \\
\text { Performance }\end{array}$ & 0.837 & 0.843 & 6 \\
\hline
\end{tabular}

\section{Exploratory Factor Analysis (EFA)}

EFA is a method used for reducing a set of variables to a minimal number of underlying factors that summarize the most important details in the variables (Richard and Dean, 2007). EFA was carried out on the 26 items by using Varimax rotation through SPSS v20. In this study, three criteria namely Government Support, Stakeholder Engagement, and Social Entrepreneurship Performance were involved in the analysis. The Kaiser-Meyer-Olkin (KMO) indices of sampling sufficiency were conducted to ensure sufficient covariance in the scale items to warrant factor analysis. The KMO index was 0.456 , which is below the acceptable limit of 0.5 . A value less than 0.50 indicates that the analysis probably will not be very useful. On the other hand, Bartlett's test of sphericity has a significant value of 0.00 , which is below 0.05 . This indicates that the factor analysis may be useful with the data (IBM, 2016).

Consequently, five factors had the eigenvalues of more than one, as portrayed in Table 3. As shown in Table 4, 26 item structures explained 76.563 per cent of variance in the result. This indicates that the items are grouped into five dimensions and would be considered for further analyses.

With an eigenvalue of 9.548, the first criterion made up for 36.724 per cent of the overall variance. As shown in Table 4, the factor loading for items in this criterion varied from 0.650 to 0.904 . The first criteria reflected the engagement made to community and local residents and they are identified as "community/local resident stakeholders". Next, the second criterion made up 54.030 per cent of the total variance with an eigenvalue of 4.500 . The factor loading for items in this criterion varied from 0.719-0.901, as shown in Table 4 . The second criterion reflected the support gained from the government and therefore, being named as "Government Support".

The third criterion made up 63.059 per cent of the total variance with an eigenvalue of 2.348. The factor loading for items in this criterion ranged from $0.772-0.858$. The third criterion reflected the engagement made to employees and thus, is labelled as "Employee Stakeholder". Furthermore, the fourth criterion made up 71.047 per cent of the total variance with an eigenvalue of 2.077. The factor loading for items in this criterion varied from 0.620 0.804 . The fourth criterion reflected the performance of social entrepreneurship dimension and hence, they are categorised as "Social Entrepreneurship Performance".

Finally, the next criterion made up 76.563 per cent of the total variance with an eigenvalue of 1.434. The factor loading for items in this criterion varied from $0.628-0.690$. The fifth criterion reflected the contribution of social enterprises towards the society and therefore, being classified as "Organisation Contribution". 
Table 3: Eigen Values, Total Variance Explained for Social Entrepreneurship Performance

\begin{tabular}{|c|c|c|c|c|c|c|c|c|c|}
\hline \multicolumn{10}{|c|}{ Total Variance Explained } \\
\hline \multirow[t]{2}{*}{$\begin{array}{l}\text { Compo } \\
\text { nent }\end{array}$} & \multicolumn{3}{|c|}{ Initial Eigenvalues } & \multicolumn{3}{|c|}{$\begin{array}{l}\text { Extraction Sums of } \\
\text { Squared Loadings }\end{array}$} & \multicolumn{3}{|c|}{$\begin{array}{l}\text { Rotation Sums of Squared } \\
\text { Loadings }\end{array}$} \\
\hline & Total & $\begin{array}{l}\% \text { of } \\
\text { Varian } \\
\text { ce }\end{array}$ & $\begin{array}{l}\text { Cumul } \\
\text { ative } \\
\%\end{array}$ & Total & $\begin{array}{l}\% \text { of } \\
\text { Varian } \\
\text { ce }\end{array}$ & $\begin{array}{l}\text { Cumula } \\
\text { tive } \%\end{array}$ & Total & $\begin{array}{l}\% \text { of } \\
\text { Varian } \\
\text { ce }\end{array}$ & $\begin{array}{l}\text { Cumulati } \\
\text { ve } \%\end{array}$ \\
\hline 1 & $\begin{array}{l}9.54 \\
8 \\
\end{array}$ & 36.724 & 36.724 & 9.548 & 36.724 & 36.724 & 6.134 & 23.591 & 23.591 \\
\hline 2 & $\begin{array}{l}4.50 \\
0 \\
\end{array}$ & 17.306 & 54.030 & 4.500 & 17.306 & 54.030 & 4.480 & 17.229 & 40.820 \\
\hline 3 & $\begin{array}{l}2.34 \\
8\end{array}$ & 9.029 & 63.059 & 2.348 & 9.029 & 63.059 & 3.984 & 15.324 & 56.145 \\
\hline 4 & $\begin{array}{l}2.07 \\
7\end{array}$ & 7.988 & 71.047 & 2.077 & 7.988 & 71.047 & 2.688 & 10.340 & 66.485 \\
\hline 5 & $\begin{array}{l}1.43 \\
4\end{array}$ & 5.516 & 76.563 & 1.434 & 5.516 & 76.563 & 2.620 & 10.078 & 76.563 \\
\hline
\end{tabular}

Table 4: The Five Criteria and Features of Social Entrepreneurship Performance

\begin{tabular}{|c|c|c|c|c|c|}
\hline & \multicolumn{5}{|c|}{ Criteria } \\
\hline & 1 & 2 & 3 & 4 & 5 \\
\hline \multicolumn{6}{|l|}{ Criteria 1: Community/Local Resident Stakeholder Engagement } \\
\hline $\begin{array}{l}\text { 1. Community Stakeholders usually urgently communicate } \\
\text { their claims to our firm }\end{array}$ & $\begin{array}{l}.90 \\
4\end{array}$ & & & & \\
\hline $\begin{array}{l}\text { 2. Local resident stakeholders have exhibited urgencies in } \\
\text { their relationship with our firm }\end{array}$ & $\begin{array}{l}.89 \\
1\end{array}$ & & & & \\
\hline $\begin{array}{l}\text { 3. Local resident stakeholders have the power to enforce their } \\
\text { claims to our firm }\end{array}$ & $\begin{array}{l}.88 \\
4\end{array}$ & & & & \\
\hline $\begin{array}{l}\text { 4. Local resident stakeholders usually urgently communicate } \\
\text { their claims to our firm }\end{array}$ & $\begin{array}{l}.86 \\
1\end{array}$ & & & & \\
\hline $\begin{array}{l}\text { 5. Local resident stakeholders have been active in pursuing } \\
\text { claims demands or desires which they deem important }\end{array}$ & $\begin{array}{l}.85 \\
5\end{array}$ & & & & \\
\hline $\begin{array}{l}\text { 6. Community stakeholders have been active in pursuing } \\
\text { claims-demands or desires which they deem important }\end{array}$ & $\begin{array}{l}.76 \\
0\end{array}$ & & & & \\
\hline $\begin{array}{l}\text { 7. Community stakeholders have exhibit urgency in their } \\
\text { relationship with our firm }\end{array}$ & $\begin{array}{l}.68 \\
7\end{array}$ & & & & \\
\hline $\begin{array}{l}\text { 8. Community stakeholders are usually viewed by our } \\
\text { management team as being legitimate }\end{array}$ & $\begin{array}{l}.65 \\
0\end{array}$ & & & & \\
\hline \multicolumn{6}{|l|}{ Criteria 2: Government Support } \\
\hline $\begin{array}{l}\text { 1. The government has supported us in seeking financial } \\
\text { resources }\end{array}$ & & $\begin{array}{l}.90 \\
1\end{array}$ & & & \\
\hline $\begin{array}{l}\text { 2. The government has supported us with necessary } \\
\text { technology information }\end{array}$ & & $\begin{array}{l}.87 \\
1\end{array}$ & & & \\
\hline $\begin{array}{l}\text { 3. The government has provided us with advantageous } \\
\text { policies }\end{array}$ & & $\begin{array}{l}.81 \\
9\end{array}$ & & & \\
\hline
\end{tabular}




\begin{tabular}{|l|l|l|l|l|}
\hline 4. We have received beneficial projects from the government & $\begin{array}{l}.81 \\
2\end{array}$ & & \\
\hline $\begin{array}{l}\text { 5. We have received direct financial assistance from the } \\
\text { government }\end{array}$ & $\begin{array}{l}.77 \\
3\end{array}$ & & \\
\hline $\begin{array}{l}\text { 6. We have been active in having government department to } \\
\text { support our activities financially. }\end{array}$ & $\begin{array}{l}.71 \\
9\end{array}$ & & & \\
\hline
\end{tabular}

\section{Criteria 3: Employee Stakeholder Engagement}

1. Employee stakeholders usually receive a high degree of time and attention from our management team

2. Employee stakeholders usually receive high priority from our management team

3. Satisfying employee stakeholders' claims has been important to our management

4. Employee stakeholders have the influence and power over our corporate decisions

5. Employee stakeholders are viewed by management team as being proper and/or appropriate

\section{Criteria 4: Social Entrepreneurship Performance}

1. We help inform the community on our beneficiaries' situation

2. We operate in a socially sustainable manner

3. We are creating employment for the socially disadvantaged class

4. Our business is social friendly

\section{Criteria 5: Organisation Contribution}

1. We set aside over two-thirds of surplus revenue for dividend for social purpose

2. Our business is eco-friendly

3. We are bringing our purpose to a greater position on the public agenda

\begin{tabular}{|l|l|l|l|l|l|}
\hline & & .85 & & \\
8 & & \\
\hline & & .84 & & \\
7 & & \\
\hline & & .82 & & \\
\hline & & & & \\
\hline & & .79 & & \\
\hline & & & & \\
\hline
\end{tabular}

Based on the findings above, the EFA results produced four independent variables of social entrepreneurship performance instead of just two in the earlier part of the study. The variables are: Community/Local Resident Stakeholder Engagement, Government Support, Employee Stakeholder Engagement, and Organisation Contribution.

Interestingly, Stakeholder Engagement, which was initially one variable, has been found to be separated into two variables namely Community/Local Resident Stakeholder Engagement, and Employee Stakeholder Engagement. This study has confirmed that the items adapted from Taghian, D'Souza, and Polonsky (2015) represent two separate variables instead of one. Furthermore, two items from Social Entrepreneurship Performance, and one item from Government Support have created another variable namely Organisation Contribution. 


\section{Conclusion and Policy Recommendation}

The test study using the reliability test and Exploratory Factor Analysis (EFA) has given a greater insight in measuring the instrument for assessing the performance of social enterprises in Malaysia. A principal component analysis was used to address the research questions and accomplish the research goal, and two variables evaluating social entrepreneurship were extended to four factors, namely community/local resident stakeholder engagement, government support, employee stakeholder engagement, and organisation contribution. Items in the research instrument used proved to be reliable and it was found that there are four underlying factors, instead of just two.

The Cronbach's Alpha value for the two dimensions of social entrepreneurship performance was high, and the Bartlett's Test had a significant value which measured the correlation strength of the factors, and the factor loadings were higher than the 0.6 limit. However, the small sample size used in this study may be acceptable for a pilot test, but it is considered small to provide a lasting conclusion. The KMO which was below 0.5 reflected an inadequate sample size and thus, the result might not be reliable or might not make a strong argument. Future research with a larger sample size might provide stronger results, and thus would give a better conclusion.

The development of the social entrepreneurship sector in Malaysia seems promising with various programmes implemented to help new social enterprises to prosper. Obstacles faced by social enterprises require a better understanding on how government support and stakeholder engagement can help to overcome those barriers. Measuring the performance of social entrepreneurship is necessary in order to know what can be done to better improve their social impact which may indicate great social enterprise performance. The results of the pilot study carried out showed that support from various parties such as the government and the local community is necessary for social enterprises to thrive and achieve their social mission. Various programmes by social enterprises such as Buy for Impact, where businesses commit to create positive social impacts and responsible buying, should be encouraged to reach more enterprises to pledge.

A specific type of business entity and legal framework for social enterprises should also be introduced to ensure they register with a business law that suits their social mission. As stated in the earlier part of this study, the absence of legal framework by the government for social enterprises may force some of them to operate without registration, and some may register their businesses with a regulation that is not compatible with their social objective. Traditional organization framework may not be relevant for social entrepreneurship due to its different structure of business models and resources. Therefore, actions should be taken to better develop the social entrepreneurship sector in Malaysia.

\section{Acknowledgement}

The authors would like to take this opportunity to express their special gratitude and appreciation to those who participated in this study. This research was funded by UiTM under the Fundamental Research Grant Scheme (FRGS) - 600-IRMI/FRGS 5/3 (148/2019), from the Ministry of Higher Education Malaysia.

\section{References}

Abbas, J., Arshad, D., \& Subramanian, C. (2019). Social Capital andSocial Enterprise Performance in Pakistan Social Innovation as a Proposed Mediator. Social Science and Humanities Journal, 3(4), 1089-1095. 
Adnan, R. M., Yusoff, W. F., \& Ghazali, N. (2018). The Role of Social Entrepreneurship in Malaysia: A Preliminary Analysis. Journal of Computational and Theoretical Nanoscience, 24(5), 3264-3269.

Ahmed, A., Khuwaja, F. M., \& Othman, N. A. (2018). Organizational Factors and Organizational Performance: A Resource-Based view and Social Exchange Theory Viewpoint. International Journal of Academic Research in Business and Social Sciences, 8(3), 579599. doi:10.6007/IJARBSS/v8-i3/3951

Austin, J. E., Stevenson, H., \& Wei-Skillern, J. (2012). Social and Commercial Entrepreneurship: Same, Different, or Both? Entrepreneurship: Theory and Pratice Journal, 370-384.

Bacq, S., \& Eddleston, K. A. (2016). A Resource-Based View of Social Entrepreneurship: How Stewardship Culture Benefits Scale of Social Impact. J Bus Ethics.

Bacq, S., \& Eddleston, K. A. (2018). A Resource-Based View of Social Entrepreneurship: How Stewardship Culture Benefits Scale of Social Impact. Journal of Business Ethics, 589611.

Barney, J. (1991). Firm resources and sustained competitive advantage. Journal of management, 17(1), 99-120.

Berg, R. G. (2021). SPSS Tutorial. Retrieved from SPSS Factor Analysis - Beginners Tutorial: https://www.spss-tutorials.com/basics/

British Council. (2018). The State of Social Enterprise in Malaysia 2018. Retrieved from British Council: https://www.unescap.org/sites/default/files/MSES-2018_Final\%20\%28lowres\%29.pdf

Cheah, J. (2018). The Determinants Of Social Enterprises Performance In Malaysia And Singapore. Universiti Sains Malaysia, 1-24.

Choi, Y., Chang, S., Choi, J., \& Seong, Y. (2018). The Partnership Network Scopes of Social Enterprises and Their Social Value Creation. International Journal of Entrepreneurship, 22(1), 1-21.

Crucke, S., \& Decramer, A. (2016). The Development of a Measurement Instrument for the Organizational Performance of Social Enterprise. Sustainability, 8(2), 161.

Dart, R. (2004). Being "business-like" in a nonprofit organization: A grounded and inductive typology. Nonprofit and Voluntary Sector Quarterly, 33(2), 290-310.

Dees, J. G. (2007). Taking Social Entrepreneurship Seriously. Society, 24-31.

de Winter, J. C., Dodou, D. I. M. I. T. R. A., \& Wieringa, P. A. (2009). Exploratory factor analysis with small sample sizes. Multivariate behavioral research, 44(2), 147-181.

Di Domenico, M., Haugh, H., \& Tracey, P. (2010). Social bricolage: Theorizing social value creation in social enterprises. Entrepreneurship Theory \& Practice, 34(4), 681-703.

Frynas, G., Mellahi, K., \& Pigman, A. (2006). First mover advantages in international business and firm-specific political resources. Strategic Management Journal, 321-345.

Hair, J. F., Babin, B., Money, A. H., \& Samouel, P. (2003). Essential of Business Research Method. United States of America: John Wiley \& Sons.

Hoogendoorn, B., Zwan, P. v., \& Thurik, R. (2011). Social Entrepreneurship and Performance: The Role of Perceived Barriers and Risk. Erasmus Research Institute of Management, 1-25.

IBM. (2016). IBM. Retrieved from KMO and Bartlett's Test: https://www.ibm.com/docs/en/spss-statistics/24.0.0?topic=detection-kmobartletts-test

Kaiser, H. (1974). An Index of Factoral Simplicity. Journal of Educational and Social Research, 6(1). 
Kassim, E. S., Tajmi, T. A., Hairuddin, H., Malik, A. M., \& Tobi, S. U. (2020). Mapping social enterprise to sustainable development goals. International Journal of Environment and Sustainable Development, 19(2).

Ladin, M. R., Abdullah, S., \& Abdulsomad, K. (2017). A concept in promoting social entrepreneurship through Malaysia Innovation and Creativity Centre for sustainability economic development in Malaysia. Journal of Education and Social Sciences, 105-109.

Lumpkin, Bacq, \& Pidduck. (2018). Where change happens: community-level phenomena in social entrepreneurship research. Journal of Small Business, 56(1), 24-50.

MaGIC. (2015). Malaysian Social Enterprise Blueprint 2015-2018. 1-88.

Mair, \& Marti. (2006). Social entrepreneurship research: A source of explanation, prediction and delight. Journal of World Business, 36-44.

Meadows, M., \& Pike, M. (2010). Performance management for social enterprises. Systemic Practice and Action Research, 23(2), 127-141.

Meyskens, M., Robb-Post, C., Stamp, J. A., Carsrud, A., \& Reynolds, P. (2010). Social ventures from a resource-based perspective: An exploratory study assessing global Ashoka Fellows. Entrepreneurship: Theory and Practice , 661 - 680.

Miller, T. L., \& Wesley, C. L. (2010). Assessing mission and resources for social change: An Organizational identity perspective on social venture capitalists' decision criteria. Entrepreneurship Theory \& Practices, 705-733.

Moizer, J., \& Tracey, P. (2010). Strategy making in social enterprise: The role of resource allocation and its effects on organizational sustainability. Systems Research and Behavioral Science, 27(3), 252-266.

Richard, J., \& Dean, W. (2007). Applied Multivariate Statistical Analysis (6th ed.). USA: Pearson Education Publication.

Santos, F. M. (2012). A positive theory of social entrepreneurship. Journal of Business Ethics, 111(3), 335-351.

Shin, C. (2018). How Social Entrepreneurs Affect Performance of Social Enterprises in Korea: The Mediating Effect of Innovativeness. Sustainability of Economy, Society, and Environment in the 4th Industrial Revolution), 10(8), 1-14. doi:10.3390/su10082643

Smith, L., \& Woods, C. (2014). Stakeholder Engagement in the Social Entrepreneurship Process: Identity, Entrepreneurship Process: Identity,. Journal of Social Entrepreneurship, 1-28.

Swanson, L. A., \& Zhang. (2010). The social entrepreneurship zone. Journal of Nonprofit \& Public Sector Marketing, 22(2), 71-88.

Tariq, Q. (2020). TheStar. Retrieved from MaGIC, now under Mosti, focuses on building startups and social enterprises: https://www.thestar.com.my/tech/technews/2020/07/02/magic-is-now-under-mosti-where-it-continues-working-to-buildtech-startups-and-social-entrepreneurs

Teck, T. S., Karuppiah, N., \& Hoo, W. C. (2020). A Critical Review on the Rise of Social Enterprise as a Foundation of Motivation and Innovation in Entrepreneurship. International Business Research, 13(1), 259-267. doi:10.5539/ibr.v13n1p259

Upadhyay, Rawal, \& Awasthi. (2017). UpLifting society by providing innovative solutions: A study of social entrepreneurship in India. International Research Journal of Engineering and Technology, 4(5), 941-951.

Vivekarajah, D. S. (2019, January 11). Putting the enterprise into social enterprises. Retrieved from Digital News Asia: https://www.digitalnewsasia.com/insights/puttingenterprise-social-enterprises 
Yunus, Moingeon, \& Lehmann-Ortega. (2010). Building social business models: lessons from the grameen experience. Long Range Planning, 308-325.

Zahra, S. A., Gedajlovic, E., Neubaum, D. O., \& Shulman, J. M. (2009). A typology of social entrepreneurs: Motives, search processes and ethical challenges. Journal of Business Venturing, 519-532.

Zahra, S. A., Newey, L., \& Li, Y. (2014). On the Frontiers: The Implications of Social Entrepreneurship for International Entrepreneurship. Entrepreneurship Theory and Practice, 137-156.

Zainol, N. R., Zainol, F. A., Ibrahim, Y., \& Afthanorhan, A. (2018). Scaling up social innovation for sustainability: The roles of social enterprise capabilities. Management Science Letters, 457-466.

Zulkepli, M., Sipan, I., \& Jibril, J. D. (2017). An Exploratory Factor Analysis and Reliability Analysis for Green Affordable Housing Criteria Instrument. International Journal of Real Estate Studies, 11(4), 9-21. 